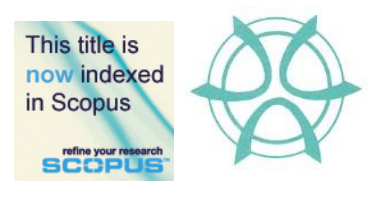

PLANNING MALAYSIA:

Journal of the Malaysian Institute of Planners

VOLUME 16 ISSUE 2 (2018), Page 109 - 118

\title{
FACTORS DETERMINING THE DEMAND FOR AFFORDABLE HOUSING
}

\author{
Xin Ying Lim¹, Abdullateef Olanrewajü, Seong Yeow Tan ${ }^{3}, \&$ Jia En Lee \\ ${ }^{1,2,3,4}$ Faculty of Engineering and Green Technology \\ UNIVERSITI TUNKU ABDUL RAHMAN MALAYSIA
}

\begin{abstract}
Affordable housing has been defined as housing which is adequate in quality and location. In addition to this, it is deemed to be housing that is not so costly that it prevents its occupants from meeting their basic living needs. This study aims to develop a framework to facilitate affordable housing delivery. The data collection used was a survey questionnaire. The survey was administered to occupants within five high-rise buildings in Penang. The study also utilized a Kaiser-MeyerOlkin measure of 0.518, and Bartlett's test of sphericity of $(x 2(210)=10953.982$, $\mathrm{p}<0.001)$. The two statistical test discovered that the major determinants affecting demand for affordable housing were crime rates, housing prices and down payments. The results also demonstrated that six factors were successfully constructed using a factor analysis and assigned as factors that determined the demand for affordable housing. The research will be useful to policy makers, urban planners, developers, and contractors.
\end{abstract}

Keywords: factors, demand, affordable housing, Malaysia 
Xin Ying Lim, Abdullateef Olanrewaju, Seong Yeow Tan, \& Jia En Lee

Factors Determining the Demand for Affordable Housing

\section{INTRODUCTION}

The concept of affordable housing is used to addresses low and medium income housing around the world. If a buyer allocates $30 \%$ of his or her gross monthly household income towards buying a house, it can be said that the housing is affordable. The US HUD (2003) noted that families who paid more than $30 \%$ of their income on housing were considered to be cost-burdened and may have difficulty affording basic necessities such as food, clothing, transportation, and medical care. In Malaysia, many households cannot afford their houses because housing prices have outstripped inflation. Housing prices in Malaysia are increasing by about $6 \%$ annually (Osman et al., 2017; "Undersupply of affordable houses", 2017). Therefore, this research aims to investigate affordable housing in Malaysia in an effort to develop a framework to facilitate affordable housing delivery.

The population in Malaysia is increasing significantly. It has been found that in the year 2010, the population was only 28.59 million, while in the year 2017, the population increased to 32.14 million (DOS, 2015).

\section{LITERATURE REVIEW}

Malaysia aims to be a fully developed country by the year 2020 . The estimated population in the year 2020 will be 32.4 million, it will comprise of 16.6 million males and 15.8 million females (DOS, 2015). The process of becoming a fully developed country has resulted in the demand for housing in Malaysia growing significantly; this has created a housing shortage. Indeed, it has been identified that were 4,945,140 residential units in the year 2016 (NAPIC, 2017a). An interpretation of the above statistics indicates a ratio of 6 people to one house. This ratio is considered high for a typical house in Malaysia with 2 to 3 bedrooms. Housing prices have increased by a record margin. For instance, between years 2009 to 2016, the house prices have increased by $46.17 \%$ all over Malaysia (NAPIC, 2017b). The average house price in Malaysia costs much more than 3 times an individual's annual median income. In median income terms, Malaysia houses are considered to be more expensive than houses in the United Kingdom, United States and Japan (Khazanah Research Institute, 2014).

The median monthly household income has increased from RM 3,626 in 2012 to RM 4,585 in 2014, this is an annual growth rate of $11.7 \%$ (DOS, 2015). Data on median monthly household income for 2016 has not been released yet, nevertheless, if a growth rate of $11.7 \%$ is applied, it is estimated that the median monthly income in 2016 would be RM 5,720. In median income terms, affordable house in Malaysia is housing that costs around 3 times an annual medium income, which is [3 x $12 \times$ RM 5,720 = RM 205,920] per house. This means that about $65 \%$ of Malaysian households cannot afford to own a house because their salary is below the estimated median income level of RM 5,720 in the year 2016. 
Malaysia is undoubtedly experiencing a shortage in the supply of affordable houses particularly in major urban areas (REHDA, 2016). The undersupply of affordable homes in the local property market is expected to deteriorate due to demographic factors and current income trends ("Undersupply of affordable houses", 2017). Since 2012, the increase in house prices in Malaysia has outstripped the rise in income levels (Cheah \& Stefanie, 2017)

\section{PROBLEM DESCRIPTION}

Houses within Malaysia are severely unaffordable (DOS, 2015). Consequently, the government has proposed schemes, programs, and incentives for developers, contractors, and homebuyers. Notwithstanding this, the prices of the houses is continuing to increase but the satisfaction levels of the homebuyers has not increased comparatively. Homebuyers seek adequate housing that they afford to purchase (NAPIC, 2017a). Homebuyers also take into account factors such good location of the housing with amenities, a secure tenure, access to housing finance and a degree of mobility and choice, when they look for a house (NAPIC, 2017a). Investigating the factors that predict homebuyer demand will facilitate decisionmaking in the delivery of affordable housing. Previous researches conducted has investigated homebuyers' requirements, nevertheless, they have not focused on affordable housing and have not analysed the interaction between the requirements.

\section{AIM AND OBJECTIVES}

The aim of the research is to develop a framework to facilitate affordable housing delivery. To achieve the aim, the following objectives have been set:

a. Prioritize the factors that affect demand for affordable housing; and

b. Categorize the factors determining demand for affordable housing.

\section{RESEARCH METHODOLOGY}

Research can be conducted through a variety of methods, but what determine the 'best' method are the purposes of the research in terms of aims, objectives, questions or hypothesis. The study utilised a survey questionnaire which collected primary data. The different variables included in the survey were adopted or adapted from literature (Li, Arditi, \& Wang, 2013; Kirkham, 2007; Royal Bank of Canada and the Pembina Institute, 2013), and the authors' experiences. The survey was administered to occupants within six high-rise buildings in Penang. The levels of importance within the survey questionnaire were measured on a Likert scale of 1 to 5 . In the scale, 1 represented extremely important, 5 denoted very low important, 3 denoted important and 2 and 4 fell in between. The housing estate was located in Penang. Each of the housing units consisted of 3 bedrooms and 2 bathrooms with a total built up area between 500 to 999 square feet. A total of 529 home owners were surveyed. 
Xin Ying Lim, Abdullateef Olanrewaju, Seong Yeow Tan, \& Jia En Lee

Factors Determining the Demand for Affordable Housing

\section{ANALYSIS AND FINDINGS}

It was found that $94.01 \%$ of the respondents agreed that 21 factors within the survey determine the demand for affordable housing in Malaysia. This is shown in Figure 1.

To further confirm the strength of the data, Bartlett's test was conducted. The results signified a lack of multicollinearity among the factors and that the respondents were drawn from those with similar experiences $(x 2(210)=$ 10953.982, $\mathrm{p}<0.001)$.

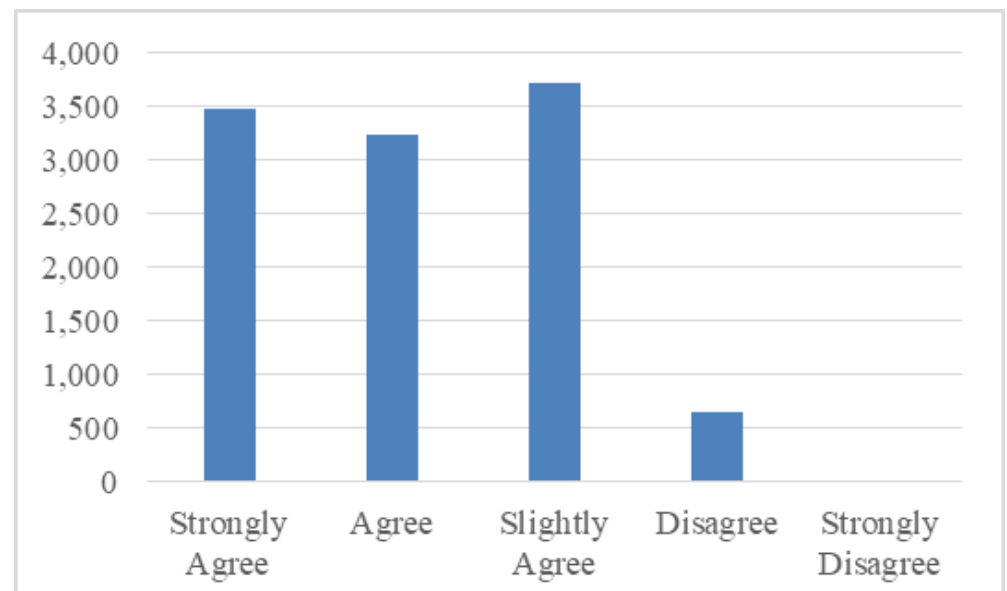

Figure 1: Factors determining the demand for affordable housing in Malaysia (Frequency)

The results shown in Table 1, also indicate that the reliability and validity of the data was very good.

Table 1: Reliability and validity of factors determining the demand for affordable housing in Malaysia

\begin{tabular}{lcccc}
\hline Factors & Reliability & Validity & Mean & $\begin{array}{c}\text { Std. } \\
\text { Deviation }\end{array}$ \\
\hline Crime Rate & 0.866 & 0.881 & 1.442 & 0.789 \\
\hline House Price & 0.860 & 0.869 & 1.692 & 0.611 \\
\hline Down Payment & 0.859 & 0.653 & 1.839 & 0.878 \\
\hline $\begin{array}{l}\text { Accessibility to } \\
\text { Working Place }\end{array}$ & 0.868 & 0.472 & 1.849 & 0.759 \\
\hline Quality of House & 0.866 & 0.768 & 1.906 & 0.885 \\
\hline $\begin{array}{l}\text { Leasehold / } \\
\text { Freehold House }\end{array}$ & 0.858 & 0.720 & 1.957 & 0.883 \\
\hline $\begin{array}{l}\text { Interest Rate on } \\
\text { Loan }\end{array}$ & 0.866 & 0.811 & 2.066 & 0.924 \\
\hline
\end{tabular}


PLANNING MALAYSIA

Journal of the Malaysia Institute of Planners (2018)

\begin{tabular}{lllll}
\hline $\begin{array}{l}\text { Access to Children } \\
\text { School \& Child } \\
\text { Day Care Centre }\end{array}$ & 0.869 & 0.768 & 2.081 & 0.768 \\
\hline Household Income & 0.866 & 0.830 & 2.087 & 1.002 \\
\hline $\begin{array}{l}\text { Ability to } \\
\text { Accommodate } \\
\text { those with Mobility }\end{array}$ & 0.851 & 0.774 & 2.098 & 0.867 \\
Restriction & 0.849 & 0.792 & 2.153 & 0.918 \\
\hline $\begin{array}{l}\text { Available of Own } \\
\text { Transports }\end{array}$ & 0.852 & 0.818 & 2.195 & 0.966 \\
\hline Neighborhood & 0.857 & 0.892 & 2.234 & 0.867 \\
\hline $\begin{array}{l}\text { House Built-up } \\
\text { Area }\end{array}$ & 0.870 & 0.765 & 2.274 & 0.841 \\
\hline $\begin{array}{l}\text { Availability of } \\
\text { Mortgages }\end{array}$ & 0.870 & 0.414 & 2.301 & 0.988 \\
\hline Family Size & 0.848 & 0.687 & 2.333 & 1.046 \\
\hline $\begin{array}{l}\text { Operation \& } \\
\text { Maintenance Costs }\end{array}$ & 0.848 & 0.911 & 2.382 & 0.86 \\
\hline Adaptability & 0.860 & 0.919 & 2.437 & 0.903 \\
\hline Type of House & 0.856 & 0.788 & 2.458 & 1.013 \\
\hline $\begin{array}{l}\text { Availability of } \\
\text { Credit/Loan } \\
\text { Facility }\end{array}$ & 0.855 & 0.818 & 2.681 & 0.747 \\
\hline $\begin{array}{l}\text { Available of Public } \\
\text { Transport }\end{array}$ & $\begin{array}{l}\text { Market/ Shopping } \\
\text { Mall }\end{array}$ & 0.892 & 2.52 & 1.035 \\
\hline
\end{tabular}

One sample t-test was computed to determine the hypothesis that each of the factors would determine demand for affordable housing in Malaysia. For this reason, the null hypothesis was that the factors would not determine the demand for affordable housing in Malaysia $\left(\mathrm{H}_{0}: \mathrm{U}=\mathrm{U}_{0}\right)$ and the research hypothesis was that the factors would determine demand for affordable housing in Malaysia (Hr: $\left.\mathrm{U}>\mathrm{U}_{0}\right)$. $\mathrm{U}_{0}$ was the population mean or comparison standard mean and the critical level off point was set at 1.5. All the factors were statistically significant. Therefore, all the factors were adequate and suitable to be included in the survey to achieve the aim of the research. 
Xin Ying Lim, Abdullateef Olanrewaju, Seong Yeow Tan, \& Jia En Lee

Factors Determining the Demand for Affordable Housing

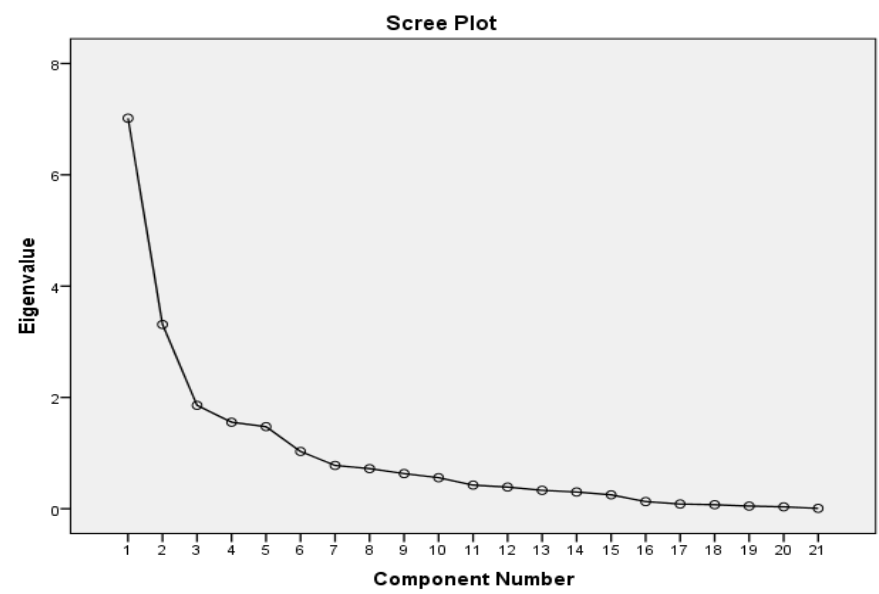

Figure 2: Factors determining the demand for affordable housing in Malaysia (Screen

Plot)

A factor analysis was used to construct the framework of the survey completed by homeowners. The Bartlett's test of sphericity and Kaiser-MeyerOlkin measure of sampling adequacy were both tests used to determine the factorability of the matrix as a whole. The resultant value of the Bartlett's test of sphericity was significant $(\mathrm{p}<0.001, \mathrm{p}=0.000)$.

Table 2 shows that there were 6 components extracted from the analysis. The eigenvalues of these 6 components was greater than 1 which was accepted in the analysis. The total percentage of variance explained by Component 1 to Component 6 was $77.349 \%$ which is considered acceptable.

The first component was named transportation cost because it comprises seven factors that determine the demand for affordable housing in Malaysia. More specifically, it explained $21.06 \%$ of the variance within the model. The factor loadings for the seven factors ranged between 0.666 to 0.866 . A secondorder factor analysis combined these seven factors into a single component named transportation cost. The Kaiser-Meyer-Olkin measure of sampling adequacy confirmed a good relationship between the factors $\left(\mathrm{MSA}=0.709, x^{2}(21)=\right.$ $3036.128, \mathrm{p}<0.001)$. The seven factors collectively explained $64.53 \%$ of the variance within the model. The validity ranged between 0.443 to 0.750 . The factors 'down payment' was the least validity (0.483). The collective Cronbach's Alpha reliability for the four factors was 0.906. All these factors relate to transportation cost that home buyers take into account when they look to purchase affordable housing. Savings from transportation cost by home owners can be used towards house purchase.

The second component was named repayment ability because it comprises five factors that determine the demand for affordable housing in 
PLANNING MALAYSIA

Journal of the Malaysia Institute of Planners (2018)

Malaysia. More specifically, it explained $15.68 \%$ of the variance within the model. The factor loadings for the five factors range between 0.640 to 0.911 . A second-order factor analysis combined these five factors into a single component named repayment ability. The Kaiser-Meyer-Olkin measure of sampling adequacy confirmed a good relationship between the factors $\left(\mathrm{MSA}=0.689, x^{2}\right.$ $(10)=1805.548, p<0.001)$. The five factors collectively explained $65.68 \%$ of the variance within the model. The validity ranged between from 0.410 to 0.829 , 'family size' was the least validity (0.410). The collective Cronbach's Alpha reliability for the three factors was 0.863 . The implication of these results indicates that homebuyers focus on ensuring that their household income will be able to cater the daily needs of their family and to pay their housing loan. Better accessibility to working place would also reduce the cost of transportation.

The third component was named limitation on consumable because it comprises three factors that determined the demand for affordable housing in Malaysia. More specifically, it explained $12.77 \%$ of the variance within the model. The factor loading for the three factors ranged between 0.833 to 0.922 . A second-order factor analysis combined these three factors into a single component named limitation on consumable. The Kaiser-Meyer-Olkin measure of sampling adequacy confirmed a good relationship (MSA $=0.668, x^{2}(3)=696.735$, $\mathrm{p}<0.001)$. The three factors collectively explained $75.68 \%$ of the variance within the model. The validity ranged between 0.695 to 0.850 , 'house built-up area' was the least validity (0.695). The collective Cronbach's Alpha reliability for the three factors was 0.831 . This means that homebuyers take into account these limitations on consumable when purchasing affordable housing.

The fourth component was named satisfaction because it comprises two factors that determined the demand for affordable housing in Malaysia. More specifically, it explained $10.47 \%$ of the variance within the model. The factor loading for the two factors was both 0.935 . A second-order factor analysis combined these two factors into a single component named satisfaction. The Kaiser-Meyer-Olkin measure of sampling adequacy indicated a good relationship between the factors (MSA $=0.500, x^{2}(1)=430.354, \mathrm{p}<0.001$ ). The two factors collectively explained $87.36 \%$ of the variance within the model. The two factors contained the same validity which was 0.874 . The collective Cronbach's Alpha reliability for the two factors was 0.827 . The results indicate that homebuyers may easily adapt to houses with prices acceptable to them. 
Xin Ying Lim, Abdullateef Olanrewaju, Seong Yeow Tan, \& Jia En Lee

Factors Determining the Demand for Affordable Housing

Table 2: Factors analysis determining the demand for affordable housing in Malaysia

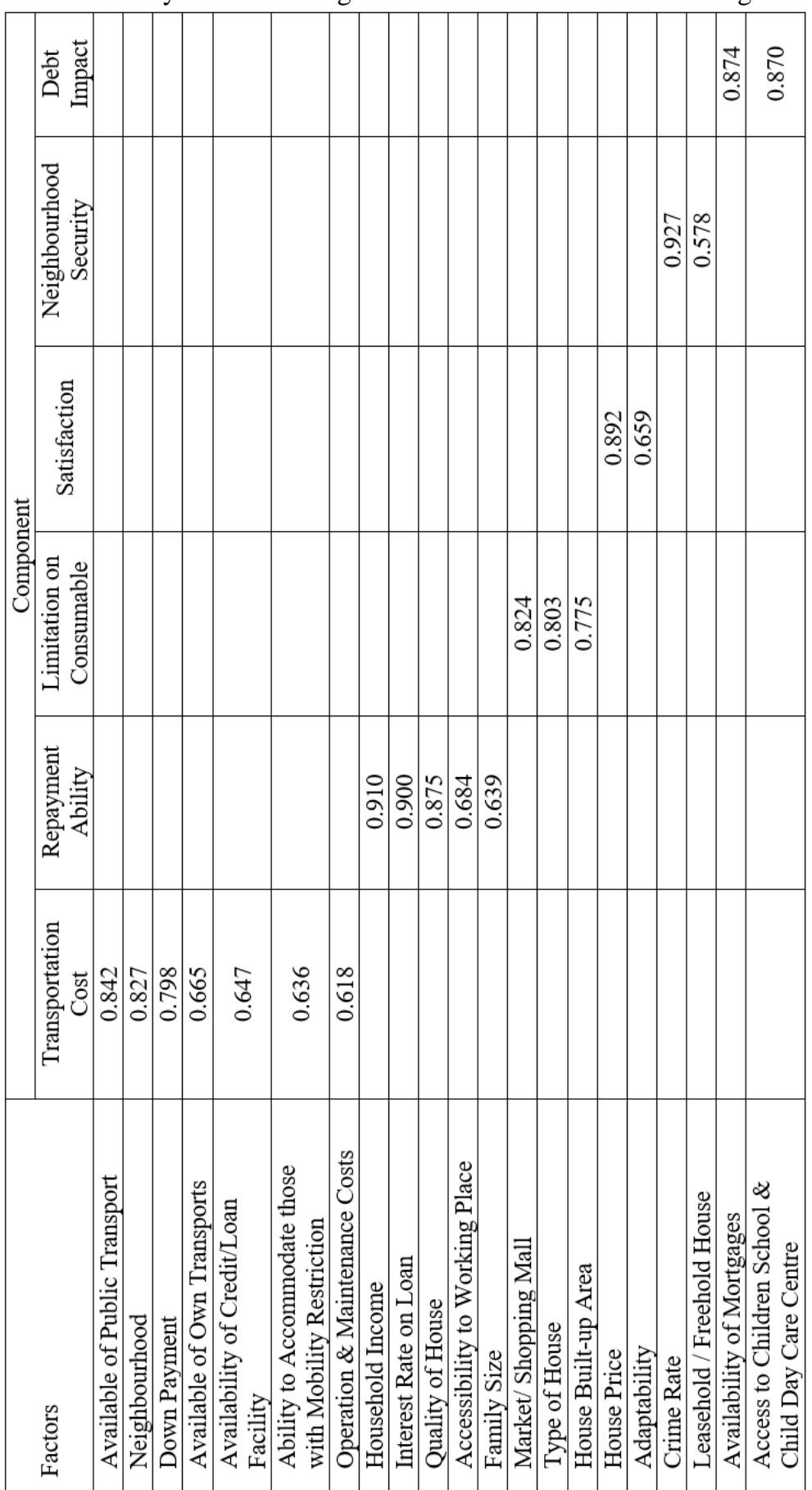


The fifth component was named neighbourhood security because it comrpises two factors that determined the demand for affordable housing in Malaysia. More specifically, it explained $9.96 \%$ of the variance within the model. The factor loading for the two factors was both 0.885 . A second-order factor analysis combined these two factors into a single component named neighbourhood security. The Kaiser-Meyer-Olkin measure of sampling confirmed a good relationship between the factors $\left(\mathrm{MSA}=0.500, x^{2}(1)=\right.$ $203.212, \mathrm{p}<0.001)$. The two factors collectively explained $78.29 \%$ of the variance within the model. The two factors contained the same validity which was 0.783 . The collective Cronbach's Alpha reliability for the two factors was 0.720 . The results mean that homebuyers were concerned about crime rate and whether the houses were leasehold or freehold when they purchased affordable housing.

The sixth component was named debt impact because it comprises two factors that determined the demand for affordable housing in Malaysia. More specifically, it explained $7.42 \%$ of the variance within the model. The factor loadings for the two factors was both 0.876. A second-order factor analysis combined these two factors into a single component named debt impact. The Kaiser-Meyer-Olkin measure of sampling adequacy confirmed a good relationship between the factors $\left(\mathrm{MSA}=0.500, x^{2}(1)=177.036, \mathrm{p}<0.001\right)$. The two factors collectively explained $87.36 \%$ in this model. The two factors contained same validity which was 0.767 . The collective Cronbach's Alpha reliability for the two factors was 0.695 . The results indicate the availability of mortgages and convenient access to schools and child day care centres were factors that affect the demand for affordable housing.

\section{CONCLUSION}

Affordable housing delivery has become a high priority for most countries as it plays a significant role in economic development and growth. While affordable housing is an abstract concept, examining the criteria that affects the housing delivery is critical. This research has investigated the demands of house buyers within the housing market by developing a framework for affordable housing. The framework critically examined the factors determining the demand for affordable housing. Policy makers, urban planners, developers, homebuyers, and contractors can use this framework in their housing decision-making processes.

Policy makers, urban planners, developers, and contractors should also be more concerned with the demand of affordable housing by median income earners within Malaysia especially in Kuala Lumpur, Penang and Johor. Majority of Malaysian living in cities have higher commitment for their basic necessities. This framework will also be able to provide insight in to their housing decisionmaking processes. 
Xin Ying Lim, Abdullateef Olanrewaju, Seong Yeow Tan, \& Jia En Lee

Factors Determining the Demand for Affordable Housing

\section{ACKNOWLEDGEMENT}

The research presented in this paper was supported in full by a grant from the "FRGS"; project: Analytical Investigation of Problems in Housing Supply in Malaysia; Project number: FRGS/1/2015/TK06/UTAR/02/2.

\section{REFERENCES}

Cheah, S. L. \& Stefanie, J. A. (2017). Demystifying the affordable housing issue in Malaysia. Bank Negara Malaysia Annual Report 2016 (pp. 90-98).

Department of Statistics Malaysia [DOS] (2015). Population and demography. Putrajaya: Author.

Khazanah Research Institute (2014). The state of households. Kuala Lumpur: Author.

Kirkham, R. (2007). Ferry and Brandon's cost planning of buildings. Oxford: Blackwell Publishing.

Li, H., Arditi, D., \& Wang, Z. (2013). Factors that affect transaction costs in construction projects. Journal of Construction Engineering and Management, 139(1), 60-68.

National Property Information Centre [NAPIC] (2017a). Summary of existing stock for residential, commercial, leisure and industrial property sub-sector as at Q1-Q4 2016. Putrajaya: Author.

National Property Information Centre [NAPIC] (2017b). Volume and Value of Property Transaction and Annual Changes 1990 - Q1 2017. Putrajaya: Author.

Osman, M. M., Ramlee, M. A., Samsudin, N., Rabe, N. S., Abdullah, M. F., \& Khalid, N. (2017). Housing affordability in state of Johor. Planning Malaysia, 15(1), $347-356$.

Real Estate and Housing Developers' Association Malaysia [REHDA] (2016). Assessing demand-supply dynamics in the Malaysian housing market.

Royal Bank of Canada and the Pembina Institute, (2013) Priced out: Understanding the factors affecting home prices in the GTA. RBC Pembina Location Matters Series.

Undersupply of affordable houses seen to worsen (2017, March 24). The Star Online. Retrieved from https://www.thestar.com.my/business/businessnews/2017/03/24/undersupply-of-affordable-houses-seen-to-worsen/

US Department of Housing and Urban Development [US HUD] (2003). Issue papers on demographic trends important to housing. 